\title{
PENDEKATAN KEADILAN RESTORATIF TERHADAP ANAK SEBAGAI PELAKU PELANGGARAN LALU LINTAS
}

\author{
Prangga Budi Laksana \\ Fakultas Hukum Universitas Bhayangkara Jakarta Raya \\ Sugeng \\ sugeng@ds.ubharajaya.ac.id \\ Fakultas Hukum Universitas Bhayangkara Jakarta Raya
}

\begin{abstract}
ABSTRAK
Dalam perkara pidana yang melibatkan anak, batasan usia sangat penting dipahami, karena digunakan sebagai acuan untuk menentukan apakah pelaku tindak pidana dapat dikategorikan sebagai anak atau bukan. Undang-Undang Sistem Peradilan Pidana Anak menentukan batas pada usia 12 (dua belas) tahun sampai 18 (delapan belas) tahun. Melalui perbandingan dua putusan pengadilan, yaitu perkara yang melibatkan Abdul Qodir Jaelani (13) dengan nomor perkara 123/PID.SUS/2014/PN.JKT.TIM dan perkara yang melinatkan Neneng Aisri dengan nomor perkara Nomor: 8/Pid.Sus-Anak/2016/PN.BKS. Perbandingan dua kasus tersebut, menunjukkan tidak adanya persamaan di muka hukum (Equality Before the Law) antara Neneng Aisri dengan Abdul Qodir Jaelani. Tulisan ini akan membahas penerapan keadilan restoratif melalui pendekatan diversi terhadap anak sebagai pelaku pelanggaran lalu lintas. Berbagai program pembinaan bagi anak yang menjalani hukuman pidana, harus sesuai dengan bakat dan minat mereka serta jenis pembinaan harus bersofat positif, tentu saja tidak sekedar mengisi waktu anak di lembaga pembinaan khusus anak, akan tetapi yang bermanfaat bagi anak, setelah anak keluar dari lembaga pembinaan ini sehingga anak dapat mengembangkan potensi dirinya dikemudian hari. Metoda penelitian yang digunakan dalam peneitian ini adalah yuridis normatif melalui kajian studi pustaka.
\end{abstract}

Kata Kunci: Anak, Keadilan Restoratif, Penerapan Diversi

\begin{abstract}
In criminal cases that involve the children, the limitation of age is very important. It is used as a reference to determine whether the offender can be categorized as a child or not. The Criminal Justice System in Indonesia determines the age limitation from 12 (twelve) years to 18 (eighteen) years. This paper will discuss the application of restorative justice through a diversion approach to the children as perpetrators of traffic accident. Through the comparison of two court decisions, namely the case involving Abdul Qodir Jaelani (13) with the cases 123 / PID.SUS / 2014 / PN.JKT.TIM and cases that dilate Neneng Aisri with th case 8 / Pid.Sus-
\end{abstract}


Anak /2016/PN.BKS. There is a comparison of the two cases, indicating the absence of equality before the law, between Neneng Aisri and Abdul Qodir Jaelani, both of which are similar case. The judges' consideration in the decision of Neneng Aisri was only burdensome, without any diversion approach. The various programs for the children must be in accordance with their talents and interests and the type of coaching should be positive, be beneficial for the child, and after the child out of this coaching children can develop their own potential in the future. In practice, the impediments of the implementation of programs that integrate socially, both education and fostering by the prison for children, which by the limited budget. This study uses normative juridical method through literature review and analysis of law.

Keywords: Child, Restorative Justice, Diversion Approach

\section{PENDAHULUAN}

Indonesia telah meratifikasi Konvensi Hak Anak atau Convention on the Right of the Child (CRC), pada tanggal 25 Agustus 1990 dengan Keputusan Presiden Nomor 36 Tahun 1990, Konvensi Hak Anak yang mengatur prinsip perlindungan hukum terhadap anak. Oleh karena itu Indonesia mempunyai kewajiban untuk memberikan perlindungan terhadap semua anak, termasuk anak yang berhadapan dengan hukum. "Anak yang berhadapan dengan hukum adalah anak yang yang berkonflik dengan hukum, anak yang menjadi korban tindak pidana, dan anak yang menjadi saksi tindak pidana” (Pasal 1 angka 2 UU No. 11 Tahun 2012 tentang Sistem Peradilan Pidana Anak).

Dalam perkara pidana yang melibatkan anak, batasan usia sangat penting dipahami, karena digunakan sebagai acuan untuk menentukan apakah pelaku tindak pidana dapat dikategorikan sebagai anak atau bukan. Undang-Undang Sistem Peradilan Pidana Anak menentukan batas pada usia 12 (dua belas) tahun sampai 18 (delapan belas) tahun. Sedangkan Undang-Undang Hak Asasi Manusia menentukan, "Anak adalah setiap manusia yang berusia di bawah 18 (delapan belas) tahun dan belum menikah, termasuk anak yang masih dalam kandungan apabila hal tersebut adalah demi kepentingannya" (UU No. Pasal 1 ayat 5 UU Hak Asasi Manusia). Sementara batasan usia anak yang ditentukan menurut hukum internasional, sebagaimana dinyatakan dalam Konvensi Hak Anak Convention On The Rights of The Child) juga pada usia di bawah 18 (delapan belas) tahun. Batas 
usia anak tersebut sesuai dengan penetapan yang digunakan oleh International Labour Organization (ILO).

Filosofi sistem peradilan pidana anak mengutamakan perlindungan dan rehabilitasi terhadap pelaku anak (emphasized the rehabilitation of youthful offender) sebagai orang yang masih mempunyai sejumlah keterbatasan dibandingkan orang dewasa. Anak memerlukan perlindungan dari negara dan masyarakat untuk kepentingan masa depannya yang masih panjang. Terhadap anak yang terlanjur melakukan tindak pidana, diperlukan strategi sistem peradilan pidana yaitu mengupayakan seminimal mungkin intervensi sistem peradilan pidana (Sulardi \& Wardoyo, 2015:261). Undang-Undang Sistem Peradilan Anak disahkan sebagai perlindungan hak konstitusional anak dalam Pasal 28B ayat (2) UUD 1945. Hal ini tertuang dalam landasan filosofis undang-undang ini guna memberikan perlindungan khusus kepada anak berhadapan dengan hukum

Data yang dihimpun oleh Komisi Perlindungan Anak Indonesia (KPAI), jumlah Anak yang berhadapan dengan hukum setiap tahunnya cukup signifikan, tahun 2011 berjumlah 695 kasus, tahun 2012 berjumlah 1413 kasus, tahun 2013 berjumlah 1428 kasus, tahun 2014 berjumlah 2208 kasus, dan pada tahun 2015 berjumlah 403. Meningkat setiap tahunnya dan menurun pada tahun 2015, termasuk didalamnya anak sebagai pelaku kecelakaan lalu lintas.

Dalam sistem peradilan pidana anak konsep keadilan Restoratif (Restorative Justice) dan konsep diversi lebih diutamakan. Kedua konsep tersebut menekankan untuk pelaku anak lebih mengutamakan proses di luar pengadilan atau non litigasi, dibandingkan dengan litigasi. Karena dalam proses keadilan restoratif dan diversi lebih mengutamakan kepentingan kedua belah pihak, dimana pihak pelaku anak diberikan perlindungan agar hak-haknya sebagai anak terpenuhi dan pihak korban diberikan ganti rugi materiil dan formil agar masalah yang terjadi dapat terselesaikan dengan baik dan bukan merupakan ajang balas dendam. Pendekatan ini perlu dilakukan, karena anak merupakan salah satu aset pembangunan nasional, patut dipertimbangkan dan diperhitungkan dari segi kualitas dan masa depannya, tanpa kualitas yang handal dan masa depan yang jelas bagi anak, pembangunan nasional akan sulit dilaksanakan dan nasib bangsa akan sulit pula dibayangkan (Bunadi Hidayat, 2010:1). 
Adanya perubahan Undang-undang nomor 3 tahun 1997 tentang Pengadilan Anak dengan lahirnya Undang-undang Nomor 11 Tahun 2012 tentang Sistem Peradilan Pidana Anak, maka dalam pasal 104 Undang-undang Nomor 11 tahun 2012 dinyatakan: Setiap Lembaga Pemasyarakatan Anak (LPA) harus melakukan perubahan sistem menjadi lembaga pembinaan khusus anak. Ditegaskan dalam pasal 85 yaitu anak yang dijatuhi pidana penjara ditempatkan di lembaga pembinaan khusus anak (LKPA).

Lembaga pembinaan khusus anak adalah lembaga atau tempat anak menjalani masa pidananya. Makna dari lembaga pembinaan khusus anak adalah sebagai wadah atau tempat bagi anak yang menjalani pidananya melalui pembinaan, pembimbingan, pengawasan, pendampingan, pendidikan, dan pelatiahn serta hak lain sesuai dengan peraturan perundang-undangan (Wangga, 2016: 234). Anak yang ditempatkan dalam lembaga pembinaan khusus anak harus terpisah dari lembaga pemasyarakatan orang dewasa, hal ini tercantum dalam pasal 85 ayat (1) UU No. 11 Tahun 2012.

Dengan demikian, regulasi yang mengatur perlindungan anak, pada prinsipnya menganut the best interests of the child, artinya pendekatan kesejahteraan dapat dipakai sebagai dasar filosofis penanganan terhadap anak yang berhadapan dengan hukum. Pendekatan prinsip the best interests of the child didasari tiga faktor sebagai berikut (Prakoso, 2016:14):

a. Anak diasumsikan belum mempunyai Legal Capacity untuk melakukan tindak pidana mengingat kondisi dan sifatnya yang masih bergantung pada orang dewasa, tingkat usia perkembangan fisik, mental, moral, spritual belum matang.

b. Anak-anak dianggap belum mengerti secara sungguh-sungguh atas kesalahan yang telah mereka perbuat sehingga sudah sepantasnya diberi pengurangan hukuman serta perbedaan pemberian hukuman bagi anakanak dengan orang dewasa bahkan dialihkan ke jalur non yuridis.

c. Bila dibandingkan dengan orang dewasa, anak-anak lebih mudah dibina dan disadarkan.

Oleh karena itu, anak yang berkonflik dengan hukum harus dilindungi haknya sebagai anak. Perlindungan anak dapat diartikan sebagai segala upaya yang 
ditujukan untuk mencegah, rehabilitasi dan memberdayakan anak yang mengalami tindak perlakuan salah, eksploitasi dan penelantaran, agar dapat menjamin kelangsungan hidup dan tumbuh kembang secara wajar, baik fisik, mental ataupun sosialnya. Tulisan ini akan membahas penerapan Keadilan Restoratif melalui pendekatan Diversi terhadap anak sebagai pelaku pelanggaran lalu lintas. Melalui perbandingan dua putusan pengadilan, yaitu perkara yang melibatkan Abdul Qodir Jaelani (13) dengan nomor perkara 123/PID.SUS/2014/PN.JKT.TIM dan perkara yang melinatkan Neneng Aisri dengan nomor perkara Nomor: 8/Pid.SusAnak/2016/PN.BKS.

Sebagai negara hukum, Indonesia sudah semestinya menjunjung tinggi hak asasi manusia (HAM) yang merupakan seperangkat hak yang melekat pada hakikat dan keberadaan manusia sebagai makhluk Tuhan Yang Maha Esa, yang wajib dihormati, dilindungi oleh negara, hukum, pemerintah dan setiap orang demi kehormatan serta perlindungan harkat dan martabat manusia. Teori perlindungan hukum merupakan salah satu teori yang penting untuk dikaji, karena fokus kajiannya pada perlindungan hukum yang diberikan kepada masyarakat, yang berada pada posisi yang lemah, baik secara ekonomis maupun lemah dari aspek yuridis. Masyarakat dalam golongan ini adalah masyarakat yang membutuhkan perlindungan dari diskriminasi politik, ekonomi, sosial, dan budaya.

Maria Theresia Game mengartikan perlindungan hukum berkaitan dengan tindakan negara untuk melaksanakan sesuatu (memberlakukan hukum negara secara eksklusif) dengan tujuan untuk memberikan jaminan kepastian hak-hak seseorang atau kelompok orang (Halim HS dan Nurbani, 2013: 262).

\section{PEMBAHASAN}

\section{Konsep Keadilan Restoratif (Restorative Justice)}

Penyelesaian perkara pidana dengan menggunakan pendekatan keadilan restoratif dengan konsisten dan sungguh-sungguh diharapkan dapat mewujudkan penegakkan hukum, yaitu keadilan, kepastian hukum, dan kemanfaatan bagi masyarakat. Pada akhirnya dapat menunjang terwujudnya suatu masyarakat yang 
tertib, tenteram, damai, adil dan sejahtera (tata tentrem kerta raharja) (Waluyo, 2016:135).

Konsep keadilan restoratif merupakan bagian dari pendekatan kesejahteraan berdasarkan doktrin Parent Patrie yang berarti negara berkewajiban untuk bertindak sebagai pelindung bagi anak-anak yang berhadapan dengan hukum atas perilakunya melalui perspektif anak yang mendasari kepentingan terbaik bagi anak. Artinya, setiap anak dipandang memiliki kemampuan untuk belajar, khususnya belajar mengubah perilakunya.

Sistem peradilan pidana anak mengatur prosedur terhadap penyelesaian persidangan anak. Undang-undang Nomor 11 Tahun 2012 tentang Sistem Peradilan Pidana Anak merupakan ketentuan khusus (Lex Spesialis) dari Kitab Undangundang Hukum Acara Pidana (Lex Generalis), artinya dalam memeriksa dan mengadili perkara anak, mengikuti ketentuan beracara yang diatur dalam Undangundang Nomor 11 tahun 2012 didahulukan dari peraturan Kitab Undang-Undang Hukum Acara Pidana (KUHAP), namun apabila ada ketentuan yang tidak diatur dalam undang-undang ini, maka digunakan ketentuan dalam KUHAP (Wangga, 2016:168).

Menurut Howard Zahr, keadilan restoratif adalah proses untuk melibatkan dengan menggunakan segala kemungkinan, seluruh pihak terkait, serta menjelaskan ancaman, kebutuhan dan kewajiban dalam rangka menyembuhkan serta meletakkan hal tersebut sedapat mungkin sesuai dengan tempatnya (Waluyo, 2016:135). Sedangkan Tony Marshall, mengatakan, "Keadilan restoratif ialah suatu proses di mana semua pihak yang bertarung dalam suatu delik tertentu berkumpul bersama untuk memecahkan masalah secara kolektif bagaimana membuat persetujuan mengenai akibat (buruk) suatu delik dan implikasinya di masa depan) (Waluyo, 2016:109).

Di sisi lain, pendekatan keadilan restoratif dalam pemidanaan Indonesia diperlukan dan diyakini dapat memberikan manfaat yang sangat berarti, baik itu bagi pelaku, korban dan masyarakatnya. Sementara bagi negara, hal ini dapat diyakini dapat membawa manfaat antara lain: 1). Tercapainya tujuan penegakan hukum yaitu keadilan, kepastian hukum, dan kemanfaatan bagi masyarakat; 2). Tercapainya cita-cita peradilan yang cepat, sederhana, murah, efektif, dan efisien; 
3). Penguatan institusi kejaksaan, aparaturnya, peran sertanya, dan peningkatan kepercayaan publik; 4). Penghematan keuangan negara, dan 5). Kelebihan kapasitas Rutan dan Lapas dapat dikurangi dan dihindari.

Dalam sistem peradilan pidana anak yang berlaku di Indonesia berdasarkan Undang-Undang Nomor 11 tahun 2012, diversi bukan hanya dapat dilakukan pada tahap pra-ajudikasi oleh penyidik dan jaksa, tetapi juga dapat dilakukan pada tahap ajudikasi oleh hakim. Pasal 7 Undang-Undang nomor 11 Tahun 2012 menegaskan bahwa pada tingkat penyidikan, penuntutan dan pemeriksaan perkara anak di pengadilan negeri, wajib diupayakan penerapan diversi. Penerapan ini dilaksanakan dalam hal tindak pidana yang dilakukan diancam dengan pidana penjara di bawah 7 Tahun dan bukan merupakan pengulangan tindak pidana (Recidivis) (Waluyo, 2016:173). Penerapan diversi merupakan pengalihan perkara anak dari proses peradilan pidana ke proses di luar persidangan peradilan pidana. Diversi bertujuan untuk: 1). Mencapai perdamaian antara korban dengan anak; 2). Menyelesaikan perkara anak di luar proses peradilan; 3). Menghindarkan anak dari perampasan kemerdekaan; 4). Mendorong masyarakat untuk berpartisipasi, dan 5). Menanamkan rasa tanggung jawab kepada anak.

Dalam Undang-undang Nomor 11 Tahun 2012, diversi diartikan sebagai pengalihan penyelesaian perkara anak dari proses peradilan pidana ke proses luar peradilan pidana berdasarkan pendekatan keadilan restoratif. Hal ini berarti konsep diversi dibentuk dalam rangka menetapkan prinsip-prinsip keadilan restoratif. Pasal 8 menentukan proses diversi dilakukan melalui musyawarah dengan melibatkan anak dan orang tua/walinya, korban dan/ orang tua dan/walinya, pembimbing kemasyarakatan, dan pekerja sosial profesional berdasarkan pendekatan keadilan restoratif. Pendekatan hukum seperti ini berupaya melindungi hak individu atau sejumlah individu, termasuk bagi anak yang berkonflik dengan hukum, yang kurang atau tidak mampu atau tidak berdaya secara fisik dan mental, secara sosial, ekonomi dan politik, baik secara preventif maupun refresif, berdasarkan hukum yang berlaku dalam upaya mewujudkan keadilan.

Dalam melakukan penyidikan, penyidik khusus anak wajib melakukan diversi paling lama 7 hari setelah penyidikan dimulai. Pada 7 hari tersebut penyidik mempertimbangkan apakah kasus anak tersebut dapat didiversi atau tidak, sesudah 
atau sebelum pelaku ditemukan penyidik wajib meminta pertimbangan dari pembimbing kemasyarakatan. Setalah itu diversi wajib dilaksanakan paling lama 30 hari, jika proses diversi berhasil maka penyidik harus membuat berita acara diversi dan kesepakatan diversi yang dilimpahkan kepada Ketua Pengadilan Negeri agar dibuatkan penetapan diversi. Namun apabila tidak ada kesepakatan untuk diversi maka berkas penyidikan dilimpahkan kepada penuntut umum untuk dibuat berkas penuntutan dan kasus anak tersebut dilanjutkan dengan melampirkan hasil penelitian kemasyarakatan.

Di dalam penuntutan, jaksa penuntut umum wajib melakukan diversi selama 7 hari, setelah berkas penyidikan diterima oleh penyidik. Penuntut umum mempertimbangkan apakah kasus anak tersebut dapat didiversi atau tidak, penuntut umum wajib meminta pertimbangan dari pembimbing kemasyarakatan kemudian diversi wajib dilaksanakan paling lama 30 hari, jika diversi berhasil maka penuntut umum wajib membuat berita acara diversi dan kesepakatan diversi dilimpahkan ke ketua pengadilan negeri agar dibuatkan penetapan diversi, namun apabila diversi tidak ditemukan kesepakatan penuntut umum wajib menyampaikan berita acara diversi dan melimpahkan kasus anak tersebut ke pengadilan dengan melampirkan hasil penelitian pembimbingan kemasyarakatan.

Penerapan diversi merupakan bentuk nyata dari keberpihakan hukum untuk menjamin pemenuhan hak-hak anak, terlebih lagi Indonesia telah meratifikasi Konvensi Hak-hak Anak (Convention On The Rights of The Child). Hak-hak anak yang diatur dalam konvensi tersebut meliputi:

a. Memperoleh perlindungan dari bentuk diskriminasi dan hukuman;

b. Memperoleh perlindungan dan perawatan seperti kesejahteraan, keselamatan, dan kesehatan;

c. Tugas negara untuk menghormati tanggung jawab, hak dan kewajiban orang tua, serta keluarga;

d. Negara mengakui hak hidup anak, serta kewajiban negara untuk menjamin perkembangan dan kelangsungan hidup anak;

e. Hak untuk memiliki jatidiri termasuk kebangsaan, nama dan hubungan keluarga;

f. Kebebasan menyatakan pendapat/pikiran ; 
g. Kebebasan berpikir, berkeyakinan dan beragama;

h. Memperoleh informasi dan aneka ragam sumber yang diperlukan;

i. Memperoleh perlindungan akibat kekerasan fisik, mental, penyalahgunaan, penelantaran atau perlakuan salah (ekploitasi) serta penyalahgunaan seksual;

j. Memperoleh perlindungan hukum terhadap gangguan (kehidupan pribadi, keluarga, surat menyurat atas serangan yang tidak sah);

k. Perlindungan anak yang tidak mempunyai orang tua menjadi kewajiban negara;

1. Hak perawatan khusus bagi anak cacat;

m. Memperoleh pelayanan kesehatan;

n. Hak memperoleh manfaat jaminan sosial (asuransi sosial);

o. Hak atas taraf hidup layak bagi pengembangan fisik, mental dan sosial;

p. Hak anak atas pendidikan;

q. Hak anak untuk beristirahat dan bersenang-senang untuk terlibat dalam kegiatan bermain, berkreasi dan seni budaya;

r. Melindungi anak dari segala bentuk eksploitasi seksual;

s. Melindungi anak terhadap semua bentuk eksploitasi terhadap segala aspek kesejahteraan anak;

t. Larangan penyiksaan dan hukuman yang tidak manusiawi;

u. Hukum acara peradilan anak; dan

v. Hak untuk memperoleh bantuan hukum baik didalam maupun di luar persidangan.

Perlindungan anak menganut prinsip the best interests of the child, kepentingan yang terbaik bagi anak yang perlu dikedepankan. Pendekatan prinsip the best interests of the child, didasari tiga faktor sebagai berikut (Prakoso, 2016:14).

a. Anak diasumsikan belum mempunyai Legal Capacity untuk melakukan tindak pidana mengingat kondisi dan sifatnya yang masih bergantung pada orang dewasa, tingkat usia perkembanga fisik, mental, moral, spritual belum matang; 
b. Anak-anak dianggap belum mengerti secara sungguh-sungguh atas kesalahan yang telah mereka perbuat sehingga sudah sepantasnya diberi pengurangan hukuman serta perbedaan pemberian hukuman bagi anakanak dengan orang dewasa bahkan dialihkan ke jalur non yuridis; dan

c. Bila dibandingkan dengan orang dewasa, anak-anak lebih mudah dibina dan disadarkan.

Dari perspektif lain, dalam konteks kehidupan anak pada struktur lapisan masyarakat dan tata kultur yang masih mendasarkan pada pola relasi antara anak dengan orang dewasa (patron-client relationship) maka anak yang melakukan tindak pidana seharusnya dipandang sebagai korban (child perspective as victim) dari berbagai faktor, misalkan kemiskinan, kurangnya perhatian keluarga dan masyarakat, keterbatasan pengetahuan orangtua atas pendidikan anak, serta pengaruh negatif dari lingkungannya. Sehingga anak melakukan tindak pidana tidak terlepas dari faktor yang melatarbelakanginya. Pada tingkat penyidikan, penuntutan dan pemeriksaan perkara anak dalam pengadilan negeri wajib diupayakan diversi. Penerapan diversi dapat dilaksanakan apabila tindak pidana yang dilakukan diancam dengan tindak pidana penjara di bawah 7 tahun dan bukan merupakan pengulangan tindak pidana. Proses diversi dilakukan melalui musyawarah dengan melibatkan anak, orang tua atau wali, pembimbing kemasyarakatan dan pekerja sosial profesional berdasarkan pendekatan keadilan restoratif.

Pada awalnya ketua pengadilan negeri harus menentukan hakim atau hakim majelis untuk menangani perkara anak dalam jangka waktu 3 hari, terhitung sejak menerima berkas perkara dari penuntut umum. Hakim wajib untuk mengupayakan diversi paling lama 7 hari setelah ditetapkan oleh ketua pengadilan negeri sebagai hakim yang menangani kasus anak tersebut. Diversi dilaksanakan paling lama 30 hari, proses diversi dapat dilaksanakan di ruang mediasi pengadilan negeri, apabila proses diversi berhasil mencapai kesepakatan hakim wajib menyampaikan berita acara diversi dan kesepakatan diversi kepada ketua pengadilan negeri untuk dibuatkan penetapan. Apabila diversi tidak mencapai kesepakatan maka kasus anak tersebut di lanjutkan ke tahap persidangan. 
Selain diatur dalam Undang-Undang Nomor 11 Tahun 2012 tentang Sistem Peradilan Pidana Anak, diversi diatur juga berdasarkan Peraturan Mahkamah Agung Nomor 4 tahun 2014 tentang Pedoman Pelaksanaan Diversi dalam Sistem Peradilan Pidana Anak. Di dalam tahap persidangan, hakim anak wajib mengupayakan diversi dalam hal anak yang didakwa melakukan tindak pidana yang diancam dengan pidana penjara dibawah 7 tahun dan didakwa pula dengan tindak pidana yang diancam penjara 7 tahun atau lebih dalam bentuk surat dakwaan subsidaritas, alternatif, kumulatif maupun kombinasi (gabungan) Penerapan diversi dalam sistem peradilan anak, meliputi: 1). Pelaksanaan Diversi di Pengadilan; 2). Tahapan Musyawarah Diversi; dan 3). Kesepakatan Diversi.

\section{Penerapan Keadilan Restoratif (Restorative Justice) dan Diversi}

Pada perkara anak yang berkonflik dengan hukum, menurut Undang-Undang Sistem Peradilan Pidana Anak, wajib disidangkan di pengadilan anak yang berada di lingkungan peradilan anak, dengan proses serta pejabat khusus yang memahami masalah anak, sejak dari penangkapan, penahanan, proses mengadili, dan pembinaan. Dari perspektif ilmu pemidanaan, penjatuhan pidana terhadap anak nakal (delinkuen) cenderung merugikan anak di masa mendatang. Dalam kenyataanya, pendekatan keadilan restoratif melalui penerapan diversi tidak selalu dapat dilakukan. Kajian selama kurun waktu tahun 2014 sampai dengan 2016 di Kepolisian Sektor (Polsek) Limo, Kota Depok, terhadap 15 (lima belas) perkara pidana di tahap penyidikan, menunjukkan adanya beberapa kendala yang menghambat implementasi penerapan diversi (Yamtoko, 2017:9). Keterbatasan sarana di tingkat penyelidikan dan penyidikan pada Polsek Limo, mungkin juga terdapat di polsek lain di wilayah Kota Depok, yang berjarak tidak jauh dari DKI Jakarta. Bahkan, untuk polsek yang letaknya jauh dari ibu kota negara, kondisinya bisa lebih buruk.

Proses penyidikan berupa penangkapan terhadap anak yang berkonflik dengan hukum, penyidik tidak menempatkan dalam ruangan khusus anak, hal ini tidak sesuai dengan Pasal 30 Ayat (2) dan (3) Undang-Undang Nomor 11 Tahun 
2012 tentang Sistem Peradilan Anak. Dalam pemberian bantuan hukum, penyidik masih kurang memfasilitasinya. Dari 15 (lima belas) perkara pidana, sepanjang tahun 2014 sampai dengan 2016, anak yang didampingi oleh penasehat hukum atau mendapat bantuan hukum kepada anak tersebut hanya ada 4 (empat) perkara pidana (Yamtoko, 2017:138).

Diabaikannya penerapan diversi bukan hanya pada tingkat penyelidikan dan penyidikan, melainkan juga terjadi pada tingkat pemeriksaan perkara di pengadilan, bahkan pada putusan pengadilan. Prosedur dalam Memutus Perkara Nomor 8/Pid.Sus-Anak/2016/PN.BKS, yang melibatkan anak (Neneng Aisri) sebagai pelaku tindak pidana, belum Sesuai dengan Undang-Undang Sistem Peradilan Pidana Anak.

Dalam prosedur persidangan Neneng Aisri belum sesuai dengan Undangundang Nomor 11 Tahun 2012 Tentang Sistem Peradilan Pidana Anak, ada beberapa hal penting yang dilewatkan, yang meliputi: 1). Pelaksanan diversi; 2). Pertimbangan pembimbing kemasyarakatan; 3). Kesempatan kepada orang tua atau wali atau pendamping untuk memberikan kesempatan untuk mengemukakan hal yang bermanfaat bagi anak. Dalam persidangan, orang tua atau wali atau pendamping tidak mengemukakan pendapat, padahal sudah tercantum dalam pasal 60 Ayat (1) UU No.11 tahun 2012.

Dalam pertimbangan hakim, hanya ada dua hal yang meringankan terdakwa Neneng Aisri yaitu: 1). Terdakwa belum pernah dihukum, dan 2). Terdakwa bersikap sopan di persidangan dan merasa menyesal serta berjanji tidak akan mengulangi perbuatannya. Jika dibandingkan dengan kasus yang melibatkan pelaku tindak pidana anak, Abdul Qodir Jaelani, pada Putusan Nomor 123/Pid.Sus/2014/PN.JKT.TIM, terdapat ketidakpastian dalam penerapan diversi sebagai pertimbangan hakim. Jika pada kasus pertama hakim menghindari penerapan diversi, pada kasus yang kedua, hakim secara optimal menerapkan diversi sebagai pertimbangan putusannya. Pertimbangan yang meringankan, meliputi (Laksana, 2017:20).

a. Terdakwa selalu menunjukan sikap yang sopan selama proses persidangan, terdakwa juga merupakan anak yang memiliki budi pekerti yang baik, terdakwa bukan seorang anak yang nakal namun hanya kurang 
perhatian dari kedua orang tuanya sehingga masih dapat dibina dan dapat memperbaiki kesalahannya, sehingga apabila terdakwa dijatuhi pidana meskipun pidana bersyarat dapat memberikan stigma negatif terhadap terdakwa dan penjatuhan sanksi pidana dapat merugikan kejiwaan anak di masa yang akan datang, karena secara kriminologis terjadinya stigmatisasi anak merupakan faktor kriminogen karena biasanya anak akan cenderung akan mengulangi perbuatan dimasa yang akan datang.

b. Telah terjadi perdamaian antara keluarga terdakwa dengan keluarga pelaku, kedua belah pihak sebenarnya tidak ingin kasus ini dibawa ke ranah hukum, karena telah diselesaikan secara kekeluargaan.

c. Keluarga terdakwa sungguh-sungguh dan secara nyata menunjukan rasa tanggung jawab terhadap para korban dan keluarga korban dengan menanggung biaya rumah sakit, memberikan biaya pemakaman dan membantu pendidikan anak-anak korban hingga ke jenjang perguruan tinggi dan keluarga terdakwa telah mengganti kendaraan korban yang rusak.

d. Orang tua terdakwa dalam persidangan menyatakan masih sanggup untuk mengasuh dan mendidik terdakwa.

e. Terdakwa menyatakan penyesalan yang sangat mendalam dan tidak akan mengulangi perbuatannya,

f. Terdakwa merupakan generasi muda penerus bangsa perlu mendapatkan kesempatan yang seluas-luasnya untuk tumbuh dan berkembang secara optimal baik fisik, mental ataupun sosial.

g. Meskipun dalam perkara ini masih diberlakukan Undang-Undang Nomor 3 Tahun 1997 tentang Pengadilan Anak, untuk menyongsong akan diberlakukannya Undang-Undang Nomor 11 Tahun 2012 tentang Sistem Peadilan Pidana Anak, maka Prinsip-prinsip dalam Undang-undang Sistem Peradilan Pidana Anak juga menjadi acuan hakim untuk menyelesaikan perkara terdakwa khususnya ketentuan tentang Restorative Justice.

Perbandingan dua kasus tersebut, menunjukkan tidak adanya persamaan di muka hukum (Equality Before the Law) antara Neneng Aisri dengan Abdul Qodir 
Jaelani, padahal kedua kasus tersebut hampir sama. Pertimbangan hakim dalam putusan Neneng Aisri hanya yang memberatkan, tanpa adanya pertimbangan pendekatan diversi. Dalam kasus Neneng Aisri ada satu hal lagi yang perlu dipertimbangkan oleh hakim yaitu antara Actus Reus (perbuatan) dan Mensrea (niat atau sikap batin).

Menurut Utrecht, Mens Rea adalah sikap batin pelaku perbuatan pidana. Berbeda dengan Actus Reus yang menyangkut perbuatan yang melawan hukum (unlawful act), Mens Rea mencakup unsur-unsur pembuat tindak pidana yaitu sikap batin yang disebut unsur subyektif suatu tindak pidana atau keadaan psikis pembuat. Perbuatan tindak pidana yang dilakukan memenuhi unsur Actus Reus, dimana unsur perbuatan Neneng Aisri terpenuhi karena melakukan penggaran lalu lintas dan meyebabkan kecelakaan lalu lintas tetapi tidak dengan unsur Mens Rea atau niat batin. Dalam kecelakaan, Neneng Aisri memenuhi delik Culpa dimana kerena kelalaian, kesalahan, kurang hati-hati, atau kealpaannya menyebabkan satu orang luka berat, bukan delik Dolus yang memperlukan unsur kesengajaan.

Dengan demikian, sudah sepantasnya Neneng Aisri mendapat perlindungan hukum secara makasimal, melalui penerapan diversi, sebagaimana diberikan pada Abdul Qodir Jaelani. Sudah pada tempatnya, jika Neneng Aisri dilindungi oleh Undang-Undang Nomor 35 tahun 2014 perubahan atas Undang-Undang Nomor 23 tahun 2002 tentang Perlidungan Anak, dijelaskan dalam pasal 16 ayat (3) penangkapan, penahanan, atau tindak pidana penjara bagi anak hanya dilakukan apabila sesuai dengan hukum yang berlaku dan hanya dapat dilakukan sebagai upaya terakhir, namun dalam kasus Neneng Aisri ketiga hal tersebut ditetapkan sebagai Premium Remedium Perbedaan perlakuan penerapan diversi pada kedua kasus tersebut dapat memperkuat stigma buruk di masyarakat, bahwa hukum hanya menguntungkan dan mengakomodasi pihak yang memiliki kekuatan secara ekonomi dan sosial saja, dan abai terhadap pihak yang lemah.

Berbagai program pembinaan bagi anak yang menjalani hukuman pidana, harus sesuai dengan bakat dan minat mereka serta jenis pembinaan harus bersifat positif, tentu saja tidak sekedar mengisi waktu anak di lembaga pembinaan khusus anak, akan tetapi yang bermanfaat bagi anak, setelah anak keluar dari lembaga pembinaan ini sehingga anak dapat mengembangkan potensi dirinya dikemudian 
hari. Sebagaimana diamanatkan oleh UU No.11 Tahun 2012 maupun oleh ketentuan perundang-undangan lainnya. Namun, dalam praktiknya, terhambatnya penerapan program yang mengintegrasikan secara sosial, baik pendidikan maupun pembinaaan oleh Balai Pemasyarakatan pada anak, disebabkan oleh terbatasnya anggaran dan kekurangan tenaga pelaksana.

\section{PENUTUP}

\section{Kesimpulan}

Tidak memadainya pengetahuan dan kecakapan penegak hukum, baik penyidik polisi, jaksa penuntut umum, maupun hakim, menyebabkan pendekatan keadilan restoratif melalui penerapan diversi terhadap anak yang berkonflik dengan hukum, menjadi terhambat. Selain itu, dukungan sarana dan prasarana yang terbatas menghalangi pemenuhan hak-hak anak yang berkonflik dengan hukum, sebagaimana telah diatur dalam ketentuan yang berlaku, baik secara internasional maupun hukum positif di Indonesia. Dalam penerapan diversi, penegak hukum di tingkat penyidikan diharapkan menyelesaikan sampai tahap akhir, dengan berkoordinasi pihak-pihak.

Indonesia mempunyai instrumen hukum yang mengatur akan hak-hak Anak, selain meratifikasi Konvensi Hak-hak anak PBB, dan telah mengesahkan UndangUndang Nomor 35 Tahun 2014 Perubahan atas Undang-Undang Nomor 23 Tahun 2002 tentang Perlindungan Anak. Dalam pelaksanaannya Undang-Undang Perlindungan Anak tersebut masih jauh dari harapan, di mana kesenjangan ekonomi, pendidikan dan sosial yang sangat berpengaruh dalam pelaksanaan Undang-undang tersebut, padahal dalam hukum semua anak Indonesia mempunyai kedudukan yang sama, setara dan seimbang (Equality Before the Law) sesuai yang diamanatkan oleh Undang-undang Dasar 1945 dalam Pasal 27 ayat (1) dan Pasal 28D Ayat (1) yang menjelaskan bahwa seluruh warga negera Indonesia mempunyai kedudukan yang sama di hadapan hukum, termasuk Anak-anak. 


\section{Saran}

Untuk lebih memperdalam pemahaman terhadap penerapan diversi perlu dilakukan penelitian lanjutan pada kasus-kasus lain yang pelakunya anak di bawah umur. Kajian perlu dilakukan di beberapa daerah, sehingga dapat diperoleh gambaran yang lebih lengkap berbagai persoalan yang menghambat dilakukannya penerapan diversi dan pemahaman para penegak hukum terhadap konsep pendekatan keadilan restoratif dan diversi.

\section{DAFTAR PUSTAKA}

Budi Laksana, Prangga. (2017). "Penerapan Keadilan Restoratif Bagi Anak yang Berhadapan dengan Hukum”. Skripsi Universitas Bhayangkara Jakarta Raya.

Hidayat, Bunadi. (2010). Pemidanaan Anak di Bawah Umur. Bandung: PT.Alumni.

Sulardi \& Wardoyo YP. 2015. "Kepastian Hukum, Kemanfaatan dan Keadilan Terhadap Perkara Pidana Anak", Jurnal Yudisial, Volume 8 Nomor 3.

Prakoso, Abintoro. (2016). Pembaruan Sistem Peradilan Pidana Anak. Yogyakarta: Aswaja Pressindo.

Waluyo, Bambang. (2016). Penegakan Hukum di Indonesia. Jakarta: Sinar Grafika..

Yamtoko, Ismu. (2017). "Perlindungan Hukum Terhadap Anak yang Berkonflik dengan Hukum di Tingkat Penyidikan: Studi Kasus Polsek Limo, Kota Depok)". Skripsi Universitas Bhayangkara Jakarta Raya.

Republik Indonesia, Undang-Undang Nomor 11 Tahun 2012 tentang Sistem Peradilan Pidana Anak, Lembaran Negara Republik Indonesia (LNRI) Tahun 2012 Nomor 153, dan Tambahan Lembaran Negara Nomor 5332, Pasal 1 angka 2.

Republik Indonesia, Undang-Undang tentang Hak Asasi Manusia, UU Nomor 39 Tahun 1999, LN Nomor 165 Tahun 1999, TLN Nomor 3886, Pasal 1 Ayat (5).

Republik Indonesia, Peraturan Mahkamah Agung Nomor 4 tahun 2014, pasal 3. 